\title{
ResearchArticle
}

\section{Path analysis studies for quantitative traits in sesame (Sesamum indicum L.)}

\author{
S.S. Tidke, S.B. Ghuge, M.P. Wankhade, D.S. Sutar and A.D. Autade
}

\section{SUMMARY}

The present investigation on path analysis studies for quantitative traits in sesame (Sesamum indicum L.) was undertaken at experimental farm of AICRP on Safflower, Vasantrao Naik Marathwada Krishi Vidyapeeth, Parbhani, Maharashtra. The experimental material consisted of Thirty four sesame germplasm lines including one check evaluated during Kharif, 2016 in Randomized Block Design with three replications. The observations were recorded on 12 characters viz., days to 50 per cent flowering, plant height, number of primary branches per plant, number of capsules per plant, capsule length, capsule breadth, number of seeds per capsule, 1000 seed weight, days to maturity, oil content, seed yield per plant and per ha. The path co-efficient analysis revealed that, days to 50\% flowering (G-2.9535) exerted the highest positive direct effect on seed yield per hectare followed by number of seeds per capsule (G-0.4577), seed yield per plant (G-0.3793), number of primary branches per plant (G-0.3587) and number of capsules per plant (G-0.0175).

Key Words : Path analysis, Sesame, Genotype, Direct effect, Indirect effect

How to cite this article : Tidke, S.S., Ghuge, S.B., Wankhade, M.P., Sutar, D.S. and Autade, A.D. (2018). Path analysis studies for quantitative traits in sesame (Sesamum indicum L.). Internat. J. Plant Sci., 13 (1): 51-54, DOI: 10.15740/HAS/IJPS/ 13.1/51-54.

Article chronicle : Received : 23.09.2017; Revised : 15.11.2017; Accepted : 29.11.2017

$\longrightarrow$ MEMBERS OF THE RESEARCH FORUM

Author to be contacted :

S.B. Ghuge, AICRP on Safflower, Vasantrao Naik Marathwada Krishi

Vidyapeeth, Parbhani (M.S.) India

Email : sbghuge@ rediffmail.com

Address of the Co-authors:

S.S. Tidke, M.P. Wankhade, D.S. Sutar and A.D. Autade, AICRP on Safflower, Vasantrao Naik Marathwada Krishi Vidyapeeth, Parbhani (M.S.) India 